\title{
Chinese consumer finance: a primer
}

Kerry Liu

\author{
Correspondence: Kerry.luke@gmail. \\ com \\ The China Studies Centre, Level 7 \\ Jane Foss Russell Building (G02) 156 \\ City Road, The University of Sydney, \\ Darlington, NSW 2006, Australia
}

\begin{abstract}
Chinese consumer finance has been booming recently, especially since 2014. However, research on this topic is scant. This study presents an updated analysis, providing original, significant contributions for academics, investors, and policymakers. We explore five perspectives: (1) macroeconomics: policies adopted by the Chinese government to enhance economic growth through promoting personal consumption; (2) financial market: China's different types of consumer finance institutions and their financing; (3) consumers: improvements in financial inclusion and consumer protections; (4) regulations in the context of supply-side structural reforms; and (5) potential areas for future academic research.

Keywords: Consumer finance, Consumer credit, Consumption, Licensed consumer finance company, Internet finance, Asset-backed security (ABS), Peerto-peer (P2P)
\end{abstract}

\section{Introduction}

The Chinese consumer finance market has been booming recently. For example, as of January 2019, the outstanding balance of Chinese consumer loans, ${ }^{1}$ excluding mortgages and auto loans, was RMB9.3 trillion (about USD1.4 trillion), compared to just RMB3.5 trillion in January 2015 (about USD563.1 billion). The compounded annual growth rate was $27.4 \%$ for 2015-2019. At the same time, many Chinese consumer finance companies have chosen to be listed publicly to help finance business expansions: There were only two Chinese consumer finance companies listed in the United States initially (one in 2010 and the other in 2014), but six more were added in 2017 and another five in $2018 .^{2}$

However, consumer finance remains relatively new to the Chinese market. Although Chinese commercial banks began providing consumer loans in 1987, the services remained immature for the first decade. In 2009, the China Banking Regulatory Commission (CBRC; now the China Banking and Insurance Regulatory Commission, CBIRC) issued the Pilot Management Measures for Consumer Finance Companies (CBRC 2009), signaling the start of the consumer finance industry in China. After a few years of steady

\footnotetext{
${ }^{1}$ This definition of consumer loans (i.e., excluding mortgage loans and auto loans) comes from Pilot Management Measures for Consumer Finance Companies (2009) and Pilot Management Measures for Consumer Finance Companies (2013). In this study, consumer finance mainly means consumer loans, that is, the borrowing and credit side of consumer finance.

${ }^{2}$ Source: Wind, People's Bank of China. The People's Bank of China only started publishing consumer loan data in 2015.
}

\section{Springer Open}

(c) The Author(s). 2020 Open Access This article is licensed under a Creative Commons Attribution 4.0 International License, which permits use, sharing, adaptation, distribution and reproduction in any medium or format, as long as you give appropriate credit to the original author(s) and the source, provide a link to the Creative Commons licence, and indicate if changes were made. The images or other third party material in this article are included in the article's Creative Commons licence, unless indicated otherwise in a credit line to the material. If material is not included in the article's Creative Commons licence and your intended use is not permitted by statutory regulation or exceeds the permitted use, you will need to obtain permission directly from the copyright holder. To view a copy of this licence, visit http://creativecommons.org/licenses/by/4.0/. 
development, since 2013, driven by government policies and the development of ecommerce and Internet technology, the Chinese consumer finance market has been developing rapidly. Figure 1 shows the size of Chinese consumer loans excluding mortgages and auto loans, the growth, and the ratio of consumer loans to total RMB loans.

Figure 1 shows that as of April 2019, the size of Chinese consumer loans was RMB 9.4 trillion (equivalent to USD1.4 trillion). Although the growth slowed down somewhat since then, it is still growing at a rate of $20 \%$ on a year-over-year basis. As of April 2019, consumer loans accounted for around $6.6 \%$ of all Chinese banking sector RMB loans. However, this consumer loan data does not include peer-to-peer (P2P) or other Internet-based consumer loans which have been estimated to be at least RMB 2 trillion (China International Capital Corporation 2018).

Campbell (2006) defined household finance as how households use financial instruments to attain their objectives. More broadly, Tufano (2009) argued that consumer finance is the study of how institutions provide goods and services to satisfy the financial functions of households, how consumers make financial decisions, and how government actions affect the provision of financial services. Tufano (2009) also argued that the main reason consumer finance has received so little attention in business schools and mainstream economic departments is that consumer finance is inherently multidisciplinary, involving not only finance and economics but also psychology, sociology, industrial organization, and the law. Tufano (2009) identified four primary and necessary functions of the consumer finance sector: moving funds, managing risk, advancing funds from the future to today, and advancing funds from today until a later date. Guiso and Sodini (2013) provided an overview of the most recent advances in the theory and evidence of how households achieve their objectives through financial markets. Badarinza et al. (2016) explored the features of household financial systems in

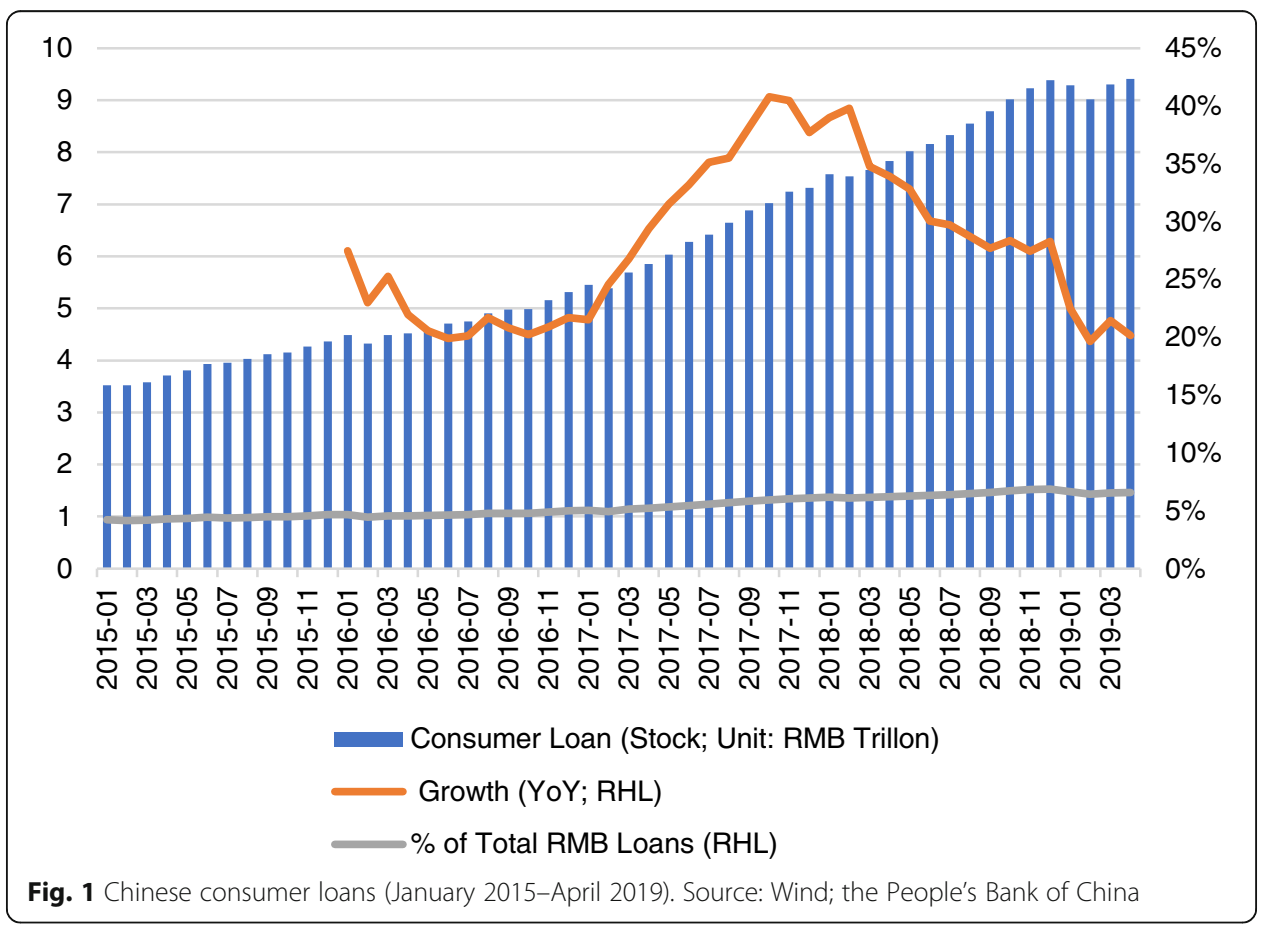


different countries, how they change over time, and the possible determinants and consequences of these international differences. In terms of the Chinese market, Oxhorn (2012) offered the first scholarly overview of the Chinese consumer finance industry, stating that would be impossible for China to liberalize its consumer finance system. However, Chinese consumer finance has now attracted substantive attention from consumers, financial institutions, investors, and government and regulatory authorities. This study presents an updated analysis of this booming market.

The structure of this paper is as follows. Section 2 evaluates Chinese consumer finance from the perspective of macroeconomics, including its role in enhancing consumption and economic growth. Section 3 is from the perspective of financial market, including the market players and financing. Section 4 is from the perspective of consumers. Section 5 addresses the perspective of government and regulatory authorities. Section 6 discusses areas for future academic research. Section 7 provides conclusions.

\section{Macroeconomic perspective}

The Chinese consumer finance market has a strong background in macroeconomics. After the stimulus programs launched during the global financial crisis of 2008-2009, China's economic growth rate declined continuously, to 6.4\% in Q1 of 2019 (see Fig. 2). As argued by Liu (2018a), the change in China's growth trends reflected both cyclical and structural problems, but mainly structural ones. The main reason lies in its potential GDP growth rate.

From the supply-side viewpoint, the potential GDP growth rate is determined by three factors: labor, capital, and total factor productivity. First, China's ongoing transition from a relatively young workforce to a more elderly population has affected China's demographic dividend. Second, much evidence shows that China has been

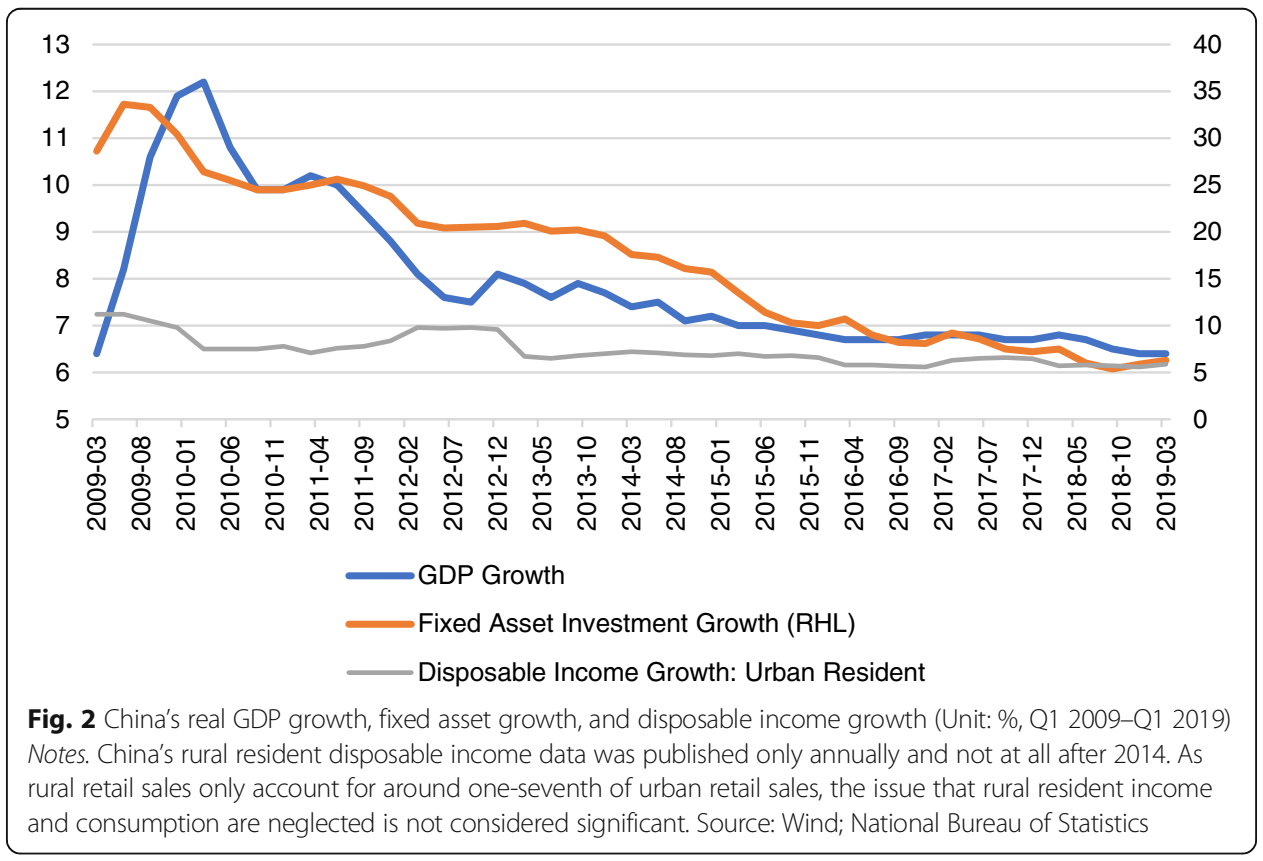


overinvesting in many sectors (in fact, reducing overcapacity is a key task for the Chinese government from 2016 to 2020). That is one reason why fixed-asset investment growth has been declining continuously as well (see Fig. 2). Third, as the surplus labor force has become gradually absorbed by the expansion of secondary and tertiary sectors, mass labor migration has slowed, and the opportunity to enhance resource allocative efficiency has narrowed.

One possible solution is to transform the Chinese economy to follow a consumptiondriven growth path, and this has been widely discussed by scholars such as Lardy (2016). However, Liu (2018b) reviewed China's three types of consumption data-i.e., GDP approach, survey data, and retail sales data-and found that all have shown a declining growth recently. Based on the retail sales data during Q1 2012-Q4 2017, Liu (2018b) found that disposable income has played a significant role in consumption growth. However, China's disposable income growth has been generally sluggish since 2009 (see Fig. 2). The question remains whether consumption will play a main role in driving China's future economic growth.

Under such conditions, promoting consumption through ways other than improving disposable income-for example, through consumer finance-provides potential solution. Evidence shows that consumer loans are closely associated with retail sales. Figure 3 shows the rolling correlation coefficients between consumer loan growth and retail sales growth between February 2016 and April 2019. As can be seen from Fig. 3, a 0-m lag means that the lag between the dates of consumer loan growth and retail sales growth is zero; a 1-m lag means that consumer loan growth was 1 month ahead of retail sales growth; and 2-m lag means that consumer loan growth was 2 months ahead of retail sales growth. The correlation coefficient in October 2017 measures the correlation between consumer loan growth and retail sales growth between February 2016 and October 2017 (because of the spring festival effect, China's National Bureau of Statistics does not publish January retail sales data).

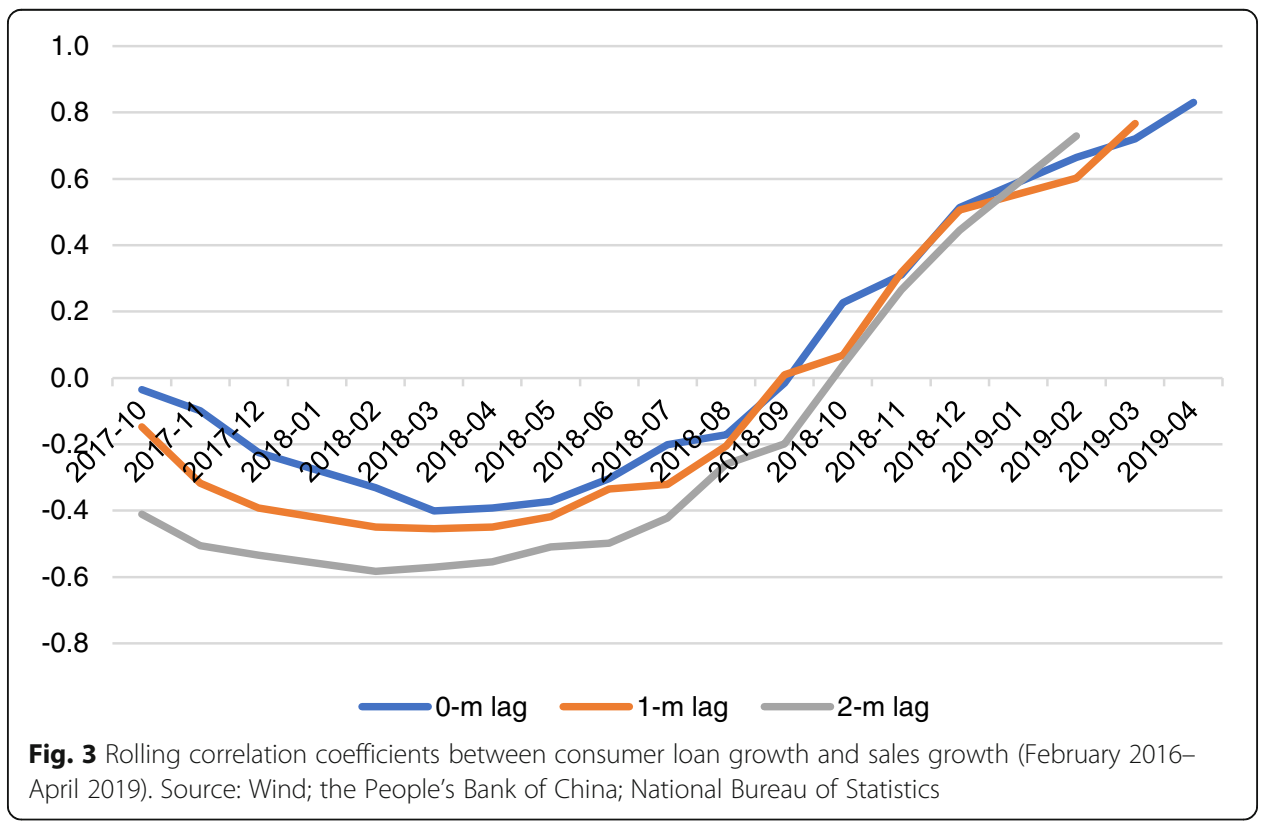


Figure 3 shows that the rolling correlation between consumer loan growth and retail sales growth has been growing stronger. The most recent data show that this correlation was strong: 0.83 for the $0-\mathrm{m}$ lag in April 2019; 0.77 for the 1-m lag in March 2019; and 0.73 for the 2-m lag in February 2019. It is reasonable to conclude that Chinese consumer finance contributed significantly to economic growth.

\section{Consumer finance: a financial market perspective}

In this section, two issues are discussed: the players in China's consumer finance market and their way of financing.

\section{Market players}

In China's consumer finance market, there are three main types of players: commercial banks, licensed consumer finance companies, and Internet-based consumer finance platforms.

\section{Commercial banks}

First, we will discuss commercial banks (mainly joint-stock commercial banks and urban commercial banks). ${ }^{3}$ The development of commercial banks' consumer finance offerings has mainly been driven by changing operational environments (Tsinghua University 2019). For example, after the interest rate liberalization of 2015 (Liu 2017), Chinese commercial banks faced greater challenges when dealing with corporate and institutional clients. Additionally, Chinese commercial banks' nonperforming loan (NPL) ratio rose from $0.9 \%$ in Q3 2011 to $1.8 \%$ in Q4 2018. Finally, according to the Administrative Measures for the Capital of Commercial Banks (for Trial Implementation) (CBRC 2012), the risk weight for corporate loans was $100 \%$ while only $75 \%$ for personal loans, meaning that more corporate loan businesses would exert more pressure on the capital adequacy indicator.

Commercial banks provide consumer finance services mainly through credit cards and consumer loans. ${ }^{4}$ Accordingly, commercial banks mainly expand their consumer finance businesses by issuing more credit cards and more consumer loans. The number of credit cards issued in China increased from 143 million in 2008 to 455 million in 2014, and the number of credit/debit cards issued increased from 433 million in Q2 2015 to 711 million in Q2 2019. ${ }^{5}$ At the end of Q4 2018, the total credits payable from credit cards was RMB 6.85 trillion; just 10 years ago, the figure was just RMB 245.8 billion, making the compounded annual growth rate from 2008 to 2018 $45.8 \%{ }^{6}$ Consumer loans also expanded, primarily in the form of diversified consumer loan products, following the upgrades in financial technology. Commercial banks dominate the Chinese consumer finance market.

Commercial banks have their own advantages in the consumer finance market-low cost of capital, a large pool of clients, numerous branches, and mature risk management

\footnotetext{
${ }^{3}$ The five largest banks in the Chinese banking system are these: Industrial and Commercial Bank of China, China Construction Bank, Bank of China, Agricultural Bank of China, and the Bank of Communications. In addition, there are 12 mid-sized joint-stock commercial banks, 133 small urban commercial banks, and over 2000 very small rural commercial banks and credit unions. There are three policy banks: Agricultural Development Bank of China, China Development Bank, and Export-Import Bank of China (Liu 2018c).

${ }^{4}$ It includes mortgage loans (not considered in this study) and credit consumer loans. Generally, consumer loans refer to credit consumer loans in this study.

${ }^{5}$ Source: Wind

${ }^{6}$ Source: Wind
} 
practices-but they have disadvantages as well. For example, their threshold of consumer loans is higher than those of licensed consumer finance companies and Internet-based consumer finance platforms.

\section{Licensed consumer finance companies}

In China, a licensed consumer finance company is a nonbanking financial institution that has been approved by the CBIRC; has its business operations under comprehensive supervision of the CBIRC; and specializes in the personal consumer loan business. Licensed consumer finance companies can absorb deposits from shareholders, borrow from China's interbank market, and issue financial bonds (after approval). However, they also must strictly operate within the scope defined by the Pilot Management Measures for Consumer Finance Companies (CBRC 2013). This can place licensed consumer finance companies at a disadvantage compared with others-especially Internetbased consumer finance platforms. Compared with commercial banks, licensed consumer finance companies issue smaller loans but can issue them quicker and with lower collateral requirements.

Consumer finance companies provide consumer loans mainly in two ways: (1) cooperation with merchants in the consumer finance business and loans directly paid to merchants that provide goods or services to consumers; and (2) direct loans to consumers. The first loan type mainly covers personal durable consumer goods such as household appliances, electronic products, and other durable consumer goods (excluding houses and cars). The second loan type covers personal uses and services, such as travel, weddings, education, renovations, and the like. Regardless of loan type, consumer finance companies that offer a combination of online and offline models are generally more competitive.

As of June 2019, there were 25 licensed consumer finance companies, including one in the process of approval (see Appendix Table 1). In accordance with the Pilot Management Measures for Consumer Finance Companies (2013) (CBRC 2013), they have both main shareholders and general shareholders: Main shareholders must hold at least $30 \%$ of the shares and the total assets of the main shareholders' from the previous financial year must not less than RMB60 billion Among those 26 licensed consumer finance companies, at least 20 had commercial banks as their main shareholders. The largest consumer finance company by registered capital in June 2019 was Home Credit Consumer Finance.

\section{Internet-based platforms}

Internet-based platforms provide consumer finance products and services online. They generally do not have consumer finance licenses or any licenses at all although some own microloan licenses. These companies can be divided into three categories: ecommerce platforms, vertical installment online platforms, and online microloan platforms. China's e-commerce platforms include JD.com (NASDAQ: JD), one of two massive Business to Customer online retailers in China by transaction volume and revenue, a member of the Fortune Global 500, and a major competitor to Tmall (run by Alibaba Group). Advantages enjoyed by e-commerce platforms include almost zero cost for obtaining customers and more efficient risk-management practices thanks to the availability of massive transaction data. China's vertical installment online platforms 
include Qudian (NYSE: QD), which targets college students and young white-collar workers buying laptops, smartphones, and other consumer electronics, and various other vertical platforms with niche positioning such as tourism, education, medical cosmetics (e.g., plastic surgery, dermatology, and cosmetic dentistry, etc.), housing, and so on. The advantages enjoyed by vertical installment online platforms are the depth and breadth of their access to specialty knowledge in a specific area, but they have the disadvantage of lacking historical transaction data for credit assessment. An example of China's online microloan platforms is Yirendai (NYSE: YRD). Compared with other consumer finance providers, online microloan platforms have higher capital costs, smaller customer pools, and less access to transaction data, so they mainly position themselves as providers of cash loans and microloans, and charge much higher interest rates.

As argued by CCWE (2019), Internet-based platforms have improved the efficiency of consumer finance by digitalizing the overall process. E-commerce platforms could further improve their efficiency by better integrating their own sales channels, and vertical installment online platforms could improve their efficiency by performing more detailed analyses in their vertical fields. For online microloan platforms, the major risk comes from regulation and the conflict between the need to expand and compliance risk.

\section{Financing}

Capital can come from many sources. Commercial banks have the lowest capital costs because they rely mainly on deposits. According to the Pilot Management Measures for Consumer Finance Companies (2013) (CBRC 2013), in addition to registered capital, licensed consumer finance companies can rely on shareholder deposits, interbank borrowing, borrowing from onshore financial institutions, issuing financial bonds, and other ways that need prior approval from the CBRC (now CBRIC). Furthermore, the interbank borrowing cannot be more than $100 \%$ of their net capital. The e-commerce platforms rely mainly on registered capital and issuing asset-backed securities (ABS), as do the vertical installment online platforms. The online microloan platforms mainly reply on P2P, making its cost of capital the highest.

\section{Shareholder capital}

The total registered capital for the 26 licensed consumer finance companies was RMB 28.2 billion (equivalent to around USD 4.3 billion $^{7}$ ) in April 2019. Furthermore, based on an incomplete list compiled by Bairong, Inc. and Tsinghua University of entities with investments of more than RMB100 million in the consumer finance industry, the investments during 2015-2017 totaled at least USD1.6 billion. ${ }^{8}$ Moreover, many companies chose to finance their domestic expansion through public offerings. Between 2010 and May 2019, there were 14 Chinese consumer finance companies listed in the United States, and the total proceeds from IPOs were USD1.64 billion (see Appendix Table 2).

\footnotetext{
${ }^{7}$ The average exchange rate between 2014 and 2018 for RMB and USD was 6.50 .

${ }^{8}$ The average exchange rate between 2015 and 2017 for RMB and USD was 6.56 .
} 


\section{Financial bonds}

Financial bonds are securities issued by financial institutions in China's national interbank bond market. Although the Pilot Management Measures for Consumer Finance Companies (2013) (CBRC 2013) stipulated that licensed consumer finance companies could issue financial bonds, doing so still requires approval from regulatory authorities. According to the Administrative Measures for the Issuance of Financial Bonds in the National Inter-bank Bond Market (PBOC 2005), issued by the People's Bank of China (PBOC; China's central bank), the criteria for issuing financial bonds have not yet been worked out for financial institutions other than policy banks, commercial banks, and corporate group finance companies. Therefore, issuing financial bonds to raise capital to finance consumer finance companies' expansion still occurs on a case-by-case basis. As of June 26, 2019, there were only three financial bond issuances from consumer finance companies: two from Bank of China Consumer Finance (one for RMB2 billion in 2016 and one for RMB1.5 billion in 2018) and one from Home Credit Consumer Finance (an RMB2 billion issuance in 2019).

ABS At present, there are three types of ABS related to consumer finance. The first is credit card-backed securities, which are mainly issued by various commercial banks. As of June 26, 2019, proceeds from ABS issues totaled RMB261.3 billion. The second type of ABS is consumer loan-backed securities, which are mainly issued by licensed consumer finance companies and some commercial banks. The Pilot Management Measures for Consumer Finance Companies (2013) (CBRC 2013) stipulated that licensed consumer finance companies could operate other businesses that had been approved by the CBRC (now CBIRC). Regarding the financing sources, recently licensed consumer finance companies are now approved to issue consumer loans-backed securities. As of June 26, 2019, proceeds from consumer loans-backed securities totaled RMB70.7 billion. The third type of ABS is microloan-backed securities. The reason for distinguishing microloans from consumer loans is that issuing them requires different licenses. The microloan license is issued by provincial regulatory authorities but under stricter restrictions on leverage than those governing consumer finance companies. For example, according to the Guiding Opinions on the Pilot Operation of Small-Sum Loan Companies Pilot issued by the (CBRC and the PBOC 2008), the balance of a microloan company's borrowing from banking financial institutions cannot exceed $50 \%$ of its net capital; that fraction is $100 \%$ for licensed consumer finance companies. Furthermore, microloan firms have fewer financing sources than licensed consumer finance companies. As of June 26, 2019, proceeds from issuing microloan-backed securities totaled RMB532.7 billion. Among them was an RMB486.3 billion (i.e., 91.3\%) issuance from Ant Financial, an affiliate of Alibaba Group, one of the world's largest retailer and ecommerce company. This shows the dominant position of the e-commerce giant in issuing microloan-based securities. ${ }^{9}$

However, whether entities are issuing financial bonds or $\mathrm{ABS}$ or borrowing from the interbank market, they all need approval from Chinese governments. Chinese consumer

${ }^{9}$ All data sets in this section are from Wind. 
finance companies, which face heavy regulations in terms of financing, need to explore more ways of financing. One important consideration when adopting different financing channels is the cost of financing. ${ }^{10}$

This section discusses three types of consumer finance firms-commercial banks, licensed consumer finance companies, and Internet-based consumer finance platforms-including their business models, target markets, and financing. Comparisons with consumer finance firms in other developed markets, such as the U.S. market, reveal both similarities and differences. For example, from 1945 to 2010, U.S. consumer finance markets experienced significant evolutions, including an increasing number of products, broadening participation of consumers in the financial sector, increasing consumer responsibility, and greater risks from consumer decisions (Trumbull and Tufano 2011). The Chinese market has been experiencing similar trends, but with several differences. For example, the growth in personal consumption followed increases in income and personal wealth (disposable income) in the United States; the ratio of household consumption to disposable personal income was almost stable from 1950 to 2010. In China, however, consumer loans grew at a much higher rate than disposable income. In the United States, do-it-yourself (DIY) finance has expanded, diversified, matured, and grown increasingly innovative, but DIY finance in China is still in its early stages.

\section{Consumer perspective}

As China's consumer finance market has been developing rapidly, there have been few studies comprehensively covering the topic from the perspective of Chinese consumers. Thus, although there have been various discussions in mass media, the profiles of consumers in the Chinese consumer finance market remain unclear. In 2018, the Centre for China in the World Economy (CCWE) surveyed 1169 of these consumers; although they tried to approximate the vast diversity of the Chinese market by covering 109 Chinese cities and 50-plus consumer finance firms, including commercial banks, consumer finance companies, and Internetbased platforms, China had a total of nearly 1.4 billion people, making the sample size too small to be significant. Nevertheless, for this immature and developing market, this study still provides some insight into the important participants in the fast-growing Chinese consumer finance market.

In the CCWE survey, $58.1 \%$ of the respondents reported that they did not have credit cards. This is consistent with the general perception that the target clients of consumer finance firms are people with no online credit record or who are not previously eligible to apply for credit cards. Considering that around $66 \%$ of the survey's respondents were between the ages of 18 and 39, China's consumer finance market appears to be most

\footnotetext{
${ }^{10}$ The financial system plays a key role in China's modern economy, which is one reason why financial regulations are important. Chinese authorities' regulation of the consumer finance sector is necessary because poorly regulated financial institutions can undermine the stability of a financial system, hurt customers' interests, and weaken the economy's prospects. However, how much and what kind of regulations should be enacted remains a topic of debate.
} 
appealing to the younger generations. Additionally, 70\% of the survey's respondents reported monthly incomes of RMB2, 000 4999, which is consistent with previous studies on credit card ownership. With respect to loan purposes, the respondents mainly used loans for home appliances, education and training, travel, and home renovation (CCWE 2018). This finding mirrors recent consumer finance business models.

In 2015, the State Council of the People's Republic of China (hereafter referred to as "State Council") issued a plan called Advancing Inclusive Financial Development, 2016-2020 (State Council 2016a). The main purpose of this plan was to offer individuals access to affordable financial products and services delivered in a responsible and sustainable way. Considering the disadvantages faced by many Chinese consumers in terms of access to financial resources, the development of the consumer finance market has improved many people's personal financial situations; human development (in terms of life expectancy, education, and per capita income, etc.) is also assumed to have improved (Nanda and Kaur 2016). At the same time, consumer credit protections remain an issue. For example, the CCWE survey found that $77.7 \%$ of its respondents reported not having any repayment arrangements in the case of financial hardship, which could compound those financial hardships.

\section{Regulatory perspective}

Before 2015, Chinese governments favored fewer regulations for its consumer finance industry. However, in what is widely considered a turning point, July 2015 marked the publication of Guideline on Promoting the Healthy Development of Internet Finance (hereafter referred to as "Guideline"), issued jointly by the PBOC, the Ministry of Industry and Information Technology of People's Republic of China (PRC), the Ministry of Public Security of the PRC, the Ministry of Finance of the PRC, the State Administration for Industry and Commerce of the PRC, the CBIRC, China Securities Regulatory Commission, the Cyberspace Administration of China (People's Bank of China, Ministry of Industry and Information Technology of People's Republic of China (PRC), Ministry of Public Security of the PRC, Ministry of Finance of the PRC, State Administration for Industry and Commerce of the PRC, CBIRC, China Securities Regulatory Commission,, and Cyberspace Administration of China 2015). The Guideline was intended to correct the fragmented and inadequate regulations prior to 2015, and it signaled strong political consensus and the will to accomplish the regulatory work (Zhou et al. 2015). Its publication was part of the array of supply-side structural reforms initiated in 2015 in which corporate deleveraging was a key task assigned by Chinese governments (Liu 2019), and it was followed by the introduction of macro-level prudential assessments by the PBOC in 2016 to prevent systemic risks to the financial system and to further countercyclical regulations (Liu 2020). The issuance of Guiding Opinions on Regulating Asset Management Business of Financial Institutions in 2018 (PBOC, CBIRC, China Securities Regulatory Commission,, and State Administration of Foreign Exchange 2018) also addressed issues with rising intrafinancial system debts and systemic risks to the Chinese financial system (Liu 2018d). 
The Guideline clarified, for the first time, the regulatory responsibilities of Chinese governments. Specifically, consumer finance-including P2P lending and online microlending-was placed under the supervision of the CBRC. The Guideline also addressed many other important issues: self-discipline in the Internet finance industry; the customer funds third-party depository system; information disclosure, risk warnings, and qualified investor systems; consumer rights and protections; Internet and information security; and the prevention and penalizing of money laundering and financial crimes.

The development of Chinese consumer finance has been accompanied by both stimulations and restrictions from regulatory authorities. Specifically, the booming consumer finance industry and its increasing correlation with retail sales as discussed earlier are the product of a series of supportive regulatory policies passed since 2013. The list below summarizes some relevant policies.

- November 2013 The CBRC (2013) issued its revised Pilot Management Measures for Consumer Finance Companies (2013). Updates to the 2009 version included: a relaxation of shareholder structuring (e.g., allowing nonfinancial Chinese firms to establish consumer finance companies; reducing the largestshareholder ownership threshold from 50\% to 30\%); improving consumer finance companies' financial strength by allowing them to absorb deposits from shareholders; relaxing operations area restrictions by extending the number of cities eligible to open consumer finance companies from four cities (i.e., Beijing, Shanghai, Tianjin, and Chengdu) to ten cities; increasing consumer loans by revising the caps from a maximum of five times the borrowers' monthly income to "up to RMB0.2 million".

- June 2015 The State Council lifted operation area restrictions to allow consumer finance companies to operate in the whole of China and delegated approval authority to provincial departments.

- December 2015 The State Council issued its Advancing Inclusive Financial Development, 2016-2020 (State Council 2016a), which stated that consumer finance companies (together with auto finance companies) and Internet-based lending firms should be further encouraged to stimulate consumption.

- March 2016 The PBOC and the CBRC jointly issued Guidance on Increasing Financial Support for New Consumption Areas (PBOC and CBRC 2016), which stated that consumer finance companies and banks should be encouraged to provide services to specific market segments, promote consumer finance products innovation, and enhance capital by issuing finance bonds, ABS, and interbank borrowings.

- April 2017 The CBR C(2017a) issued the Guiding Opinions on Improving the Efficiency of the Banking Service to the Real Economy, which stated that commercial banks should further expand their consumer finance businesses and actively meet the reasonable financing needs of consumers for bulk durable consumer goods, new consumer goods, education, and tourism. These guidelines were reiterated in August 2018, further promoting the development of consumer finance and highlighting its role in economic growth. 
- September 2018 The State Council (2018) issued the Implementation Plan for Improving and Promoting Consumption (2018-2020), which called for the further promotion of consumer finance and maintenance of the reasonable leverage level of households.

The year 2015 was a turning point. Following the issuance of the Guideline, a series of specific regulatory measures were implemented. These regulations initially focused on Internet-based consumer finance firms and consumers in 2015-2017; in April 2018, they were expanded to include the entirety of the asset management business of financial institutions. China's regulatory framework has become more mature and complex through the following actions:

- September 2015 China's Supreme People's Court, the highest court in Chinese mainland, stipulated that the annualized interest rate for online lending should not be higher than $36 \%$.

- December 2015 The PBOC, in collaboration with relevant ministries, initiated the National Internet Finance Association of China (NIFA), a national self-regulatory organization in the field of Internet finance to provide oversight and financial literacy education.

- April 2016 The State Council (2016b) issued the Implementation plan for the special rectification of Internet financial risks, stipulating that P2P lending platforms should (1) choose qualified banking financial institutions as a third party to deposit client funds; (2) act strictly as brokers rather than as financial institutions; and (3) not operate real estate-related financial businesses because the real estate industry is part of China's macroprudential assessment framework (Liu 2020) and has been under heavy regulations (Liu 2019).

- December 2016 The PBOC (2016) issued the Financial Consumer Rights Protection Implementation Measures, which addressed a series of issues, including financial institutions' code of conduct, personal financial information protections, complaint acceptance and handling, and mechanism for supervision and management.

- May 2017 The CBRC, the Ministry of Education of the PRC, and the Ministry of Human Resources and Social Security of the PRC jointly issued the Notice on Further Strengthening the Management of Campus Lending Regulations (CBRC, the Ministry of Education, and the Ministry of Human Resources and Social Security of the PRC 2017), temporarily forbidding all online lending firms from operating lending businesses in connection with school and university campuses; this came in the wake of a series of problems, including fraudulent lending practices, usurious loans, and debt collection through violent means.

- October 2017 NIF A (2017) issued the Group Standards of Internet Finance: Information Disclosure, Internet Consumer Finance. The document cited of 27 indicators, including 23 compulsory indicators, of two classification types: company information and operations information (e.g., loan collection methods, processes, and behavior guidelines). 
- December 2017 CBRC's Office of the Leading Group for the Special Remediation of Internet Financial Risks issued the Notice on Standardizing and Regulating "Cash Loan" Businesses CBRC 2017b). Cash loans are characterized by small amounts, short terms, high interest rates, and no collateral. The notice stipulated that regulatory authorities should temporarily suspend issuing licenses for microloan businesses due to a series of concerning issues: excessive borrowing/lending, improper collection, abnormal interest rates, and infringement of personal privacy. To strengthen consumer protections, the notice also stipulated that loans could not be issued to borrowers without income sources, could be extended only two times, and could not be collected by lenders or third-party agencies through violence, intimidation, insult, slander, harassment, or other similar means.

- April 2018 The PBOC, the CBIRC, China Securities Regulatory Commission, and the State Administration of Foreign Exchange jointly issued the Guiding Opinions on Regulating Asset Management Business of Financial Institutions (PBOC, CBIRC, China Securities Regulatory Commission,, and State Administration of Foreign Exchange 2018), which strengthened the regulations on leverage and product nesting, indirectly affecting the funding source of consumer finance companies.

- October 2018 The China Banking Association Consumer Finance Committee was set up with the aim of strengthening self-discipline in the consumer finance industry and formulating best practices and codes of conduct.

Zhou et al. (2015) have argued that China will likely become a leader worldwide in developing a sustainable, effective regulatory framework for Internet finance. However, for this to happen, much work remains. For example, while there are licensed consumer finance companies and licensed microloan companies, there is no such regulation of P2P lending as yet. According to the Guiding Opinions on Classifying Online Lending Institutions and Risk Prevention (CBRC 2019), most of the P2P platforms may be closed down, and the rest may be transformed into licensed microloan companies or licensed asset management companies. Four years after the issuance of the draft of comments of the Non-Deposit Lending Institution Regulations (draft for comments) (State Council 2015), it is reported that the regulations will be finalized soon. In addition, China's personal credit record system is still in its infancy. Before 2018, the PBOC Credit Reference Centre (i.e., National Financial Credit Information Basic Database) covered less than 30\% of the Chinese population (CCWE 2019). In March 2018, Baihang Credit, a personal credit agency, was established with the sponsorship of NIFA and eight other institutions, including Zhima Credit (an affiliate of Alibaba) and Tencent Credit (an affiliate of Tencent). These agencies are intended to provide unified personal credit investigation and service platforms serving the consumer finance industry.

The overall effects have been profound. First, the market players (consumer finance companies) have been negatively affected by regulations on cap lending rates, scopes of businesses, and funding sources. Second, consumers have been positively affected by stronger consumer rights protection and information disclosure requirements. Third, the whole consumer finance market in China has become more transparent and healthier as a result of stronger regulations. 


\section{Academic perspective}

Tufano (2009) classified research on consumer finance by primary decision-makers into four types: consumers, financial institutions, the government, or a combination of these players.

\section{Consumers}

Tufano (2009) argued that because financial economics has not fully embraced consumer finance topics, personal finance advice is often driven less by research than by rules of thumb. This gap in available research suggests opportunities to apply scientific methods to provide better advice and to incorporate real-world concerns into models. One important element of consumer-facing research, which spans positive and normative work, models consumer preferences, attempting to address two fundamental questions: What decisions should and do consumers make? What can explain these choices?

\section{Financial institutions}

Tufano (2009) argued that institution-facing work seeks to explain the organization, management, and choices of retail financial institutions and the implications for consumers' well-being and social welfare. These institutions include depositories, brokerage firms, mutual funds, insurance firms, networks of firms (e.g., credit card associations), P2P lenders, check cashers, payday lenders, rent-to-own stores, and pawnshops, as well as governments that sell money orders and social networks where members lend to one another.

\section{Government regulations}

Tufano (2009) argued that consumer finance should and has received extra attention. Beyond ensuring the system's safety and soundness, U.S. federal and state banking regulations are designed to protect consumers' interests. Similarly, the U.S. Securities and Exchange Commission's duty, in part, is investor protection. Some consumer financial businesses are more closely overseen than other businesses.

\section{Multiparty field interventions}

Tufano (2009) argued that a recent and important trend in consumer finance research has been the use of field experiments that not only engage multiple parties but also test the impact of interventions. Such testing can be structured in standard controltreatment fashion or as randomized field experiments in which treatments are administered randomly to increase the power of the tests.

Serious literature on Chinese consumer finance has only recently begun to appear. Daisuke et al. (2017) conducted a general review of the history and development of consumer finance in China, Japan, and South Korea. Their dataset and research into the Chinese market included mortgage loans and auto loans as of the end of 2012, so their research did not consider the boom in the consumer finance market not related to mortgages and auto loans. Another study by China Family Finance Survey and Research Center (2017), which did not go through a peer-review process, examined the heterogeneity characteristics of household finance and found that family size, education 
level, employment, household assets, household income, and family geographic location all had a significant impact on household debt. Based on a survey of 286 undergraduate students from four universities in Beijing, Hao et al. (2019) conducted an empirical analysis of the economic and social determinants of undergraduates' consumer credit. However, that research was also not validated by the traditional peer-review process. As China's Internet-based consumer finance companies have been developing very fast recently, a few studies have begun to focus on one niche area, P2P lending, examining the relations between government affiliation and the development of China's P2P lending platforms (Jiang et al. 2018); the risks associated with P2P lending platforms (Li et al. 2016); punctuation's effect on readability in the P2P lending market (Chen et al. 2018); and the reputation mechanism in P2P lending (Ding et al. 2019).

Given recent significant developments in Chinese consumer finance, there are plenty of areas for serious research, including research with a focus on consumers, consumer finance firms, government regulations, or a mixture of these.

\section{Consumer-focused research}

One important topic for future research is the relations between utility and consumer demand (Tufano 2009). Value (net present value, NPV) maximization is used as a general objective function in corporate finance. Maximization of utilities and utility functions in consumer finance have similar purposes, but modeling consumer expectations is much more difficult than estimating NPVs. The form of the utility function, the function parameters, and even the presence of rational timeconsistent decision-makers are research issues that have been studied for a long time but still lack clarity (Campbell 2006; Tufano 2009). The behavioral considerations complicate our understanding of consumers (Barberis and Thaler 2003). Thus, studies on psychology and sociology will be very helpful in understating consumer financial decisions. More studies that incorporate the characteristics of Chinese consumer preferences (e.g., Shi and Yan 2017; Shi et al. 2019) are needed. New surveys should investigate specific markets by geographical location, education level, products, or other factors rather than the whole Chinese market. Previous studies have shown that taxes (Graham 2003) and bankruptcy (Senbet and Wang 2012) are important factors that can explain corporate finance decisions. They are also important in consumer finance decisions. In July 2019, the Accelerating the Improvement of the Market Entity Exit System Reform Plan (State Council 2019), suggested that a personal bankruptcy system would be launched soon. How this will affect Chinese consumers' financial decisions will be another interesting research topic. The effect of financial skills and education on consumer financial behavior relative to China's consumer finance market needs further research (e.g., Mandell and Klein 2009).

\section{Consumer finance firm research}

One topic for future research is the organization and economics of retail financial institutions. For example, how does technological innovation change the production, operation, and business model (Devlin 1995)? The Chinese banking industry has traditionally been corporate-centric, but recently this has begun to change, with 
macroeconomic and regulatory environment changes and, of equal importance, the advances in financial technology. Further studies are thus called for. Furthermore, as of May 2019, 14 consumer finance firms were listed overseas (see Appendix Table 2), making their financial, operational, and governance information available to the public. A panel dataset could be constructed to examine a variety of corporate finance issues (Guo et al. 2018). As discussed previously, the sustainability of different consumer finance businesses such as commercial banks, licensed consumer finance companies, and Internet-based platforms should be further explored. Future studies can also examine the agency conflicts in consumer finance firms' relations with customers, including misaligned incentives between principals and agents (Allen 2001) and industry competition and its effects on customers (Dick and Lehnert 2010). For example, how does competition among commercial banks (consumer finance companies) affect the credit card (consumer loan) pricing?

\section{Regulation-focused research}

As discussed previously, 2015 was a major turning point. The Guideline (2015) and subsequent specific regulatory measures provide ample topics for serious research, including price controls, restrictions on creditor remedies, bankruptcy law, information disclosure rules, and anti-discrimination laws (Hynes and Posner 2002). For example, regulations restricted the interest rate that can be charged for consumer loans. However, this could lead consumer finance firms to refuse to lend to highrisk debtors, and this may be followed by queuing and unsatisfied demands. Future research should investigate this issue. Additionally, Chinese regulatory authorities recently restricted the use of some debt-collection mechanisms, protecting borrowers from harassing phone calls, threatening letters, defamation, and other maligning actions. Thus, there remains room for research into effective and legal repayment mechanisms and systems such as prejudgment and post-judgment remedies (Hynes and Posner 2002). Bankruptcy regulations are also a topic for future research; China needs to speed up the legislation of personal bankruptcy laws and will need studies on the structure and effects of this law. Privacy and information disclosure is another area for research. Chinese regulatory authorities' requirements on information disclosure aim to increase economic stability and help consumers shop for appropriate loan terms and prevent inaccurate charging. These goals need to be empirically assessed. Finally, discrimination in consumer finance do exist in regulations and should be further examined (Chen et al. 2017).

Future research can also examine topics that are combinations of two or more of the above subtopics-for example, personal bankruptcy from the perspectives of consumers, consumer finance firms, or law and regulations. Figure 4 shows a summary of possible future research directions or possible topics related to China's consumer finance market.

\section{Concluding remarks}

Chinese consumer finance has been booming since 2014, yet there is a need for more serious research on this topic, although there have a few fragmented studies on Internet finance (P2P lending). This primer on the China's consumer finance 


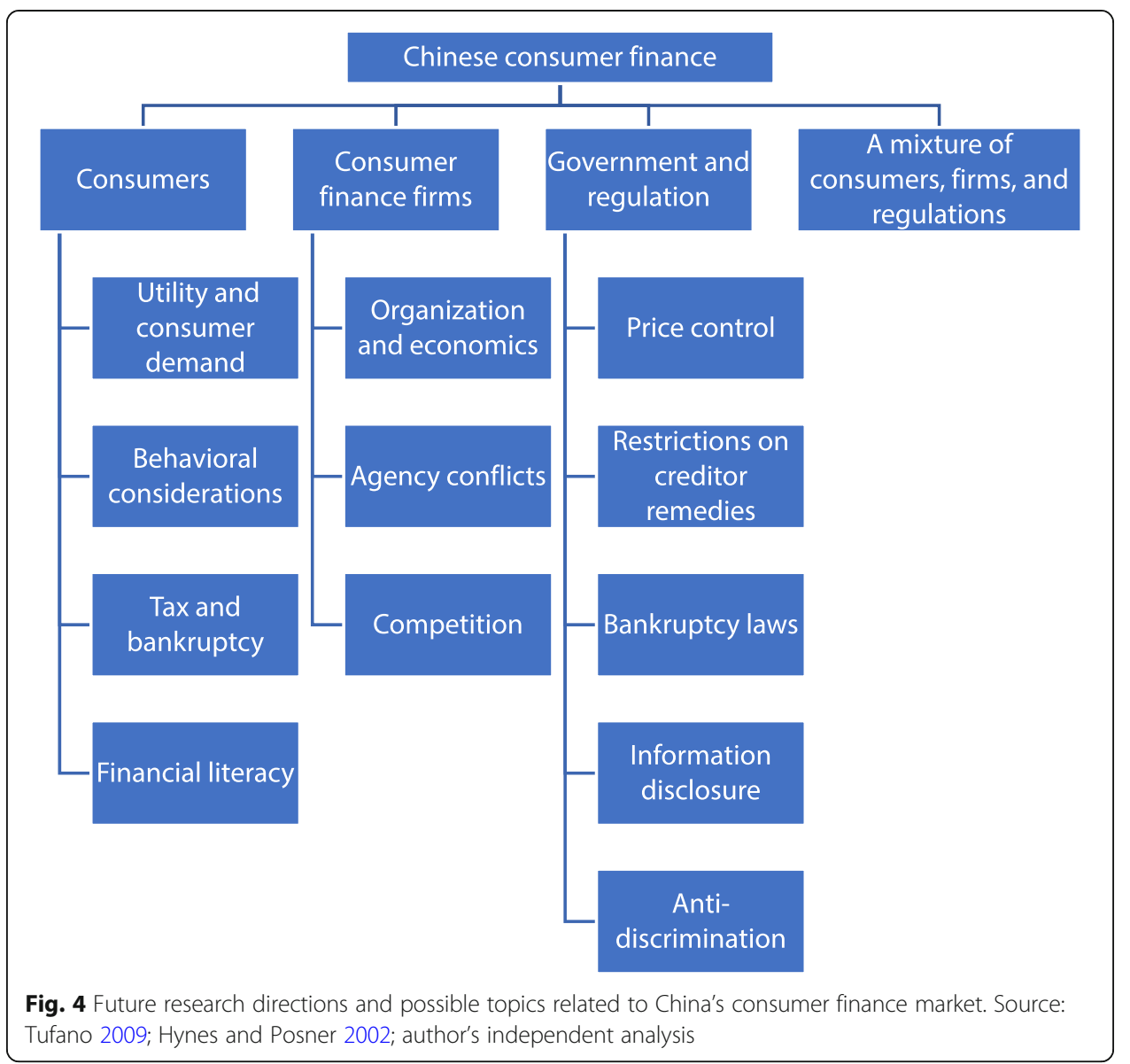

market offers three pioneering contributions. First, this study is the first of its kind to examine the macroeconomic causes of the rapid development of the Chinese consumer finance market. Second, this study looks at the big picture of Chinese consumer finance market through a few different but related lenses such as financial markets, consumers, and regulations. Accordingly, this clarifies future research areas and directions. Third, this study presents an updated analysis of the Chinese consumer finance market, which will help policymakers and investors make informed decisions.

These are the key takeaways. (1) Chinese government policies to enhance economic growth by promoting household consumption have played an important role in the development of Chinese consumer finance. (2) There are three main purveyors of consumer finance: commercial banks, licensed consumer finance companies, and Internet-based consumer finance platforms; they all have different sources of funding. (3) The development of consumer finance in China has expanded financial inclusion but, at the same time, exposed issues related to consumer credit protections. (4) Since 2017, China's consumer finance industry has experienced heavy regulations as part of the supply-side structural reforms initiated in 2015. (5) Chinese consumer finance is a potential goldmine for academic. 


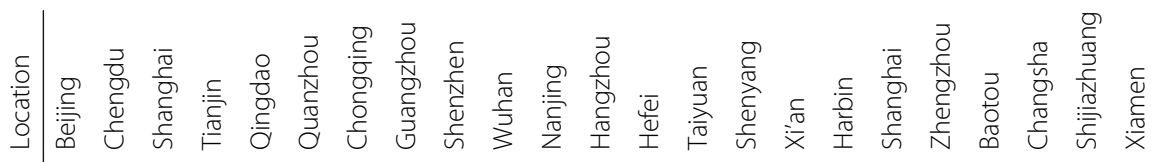

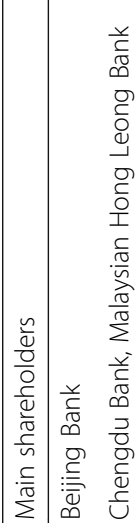

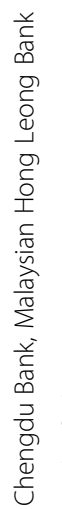

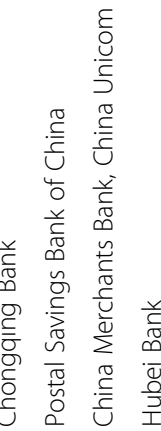

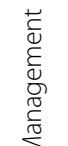

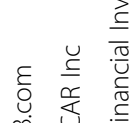

i̊

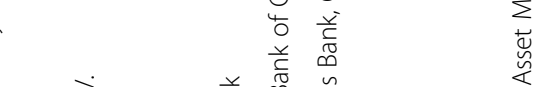

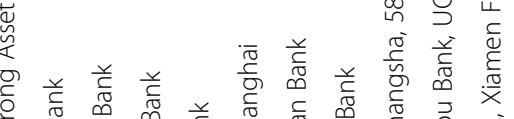

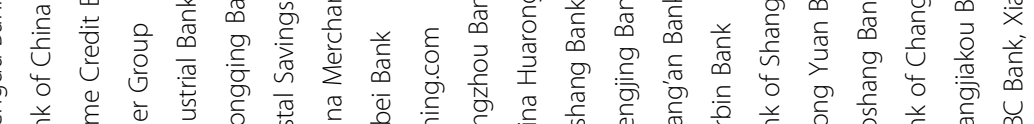

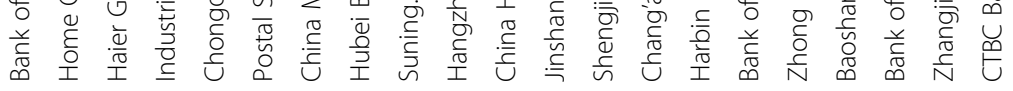

బ.

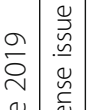

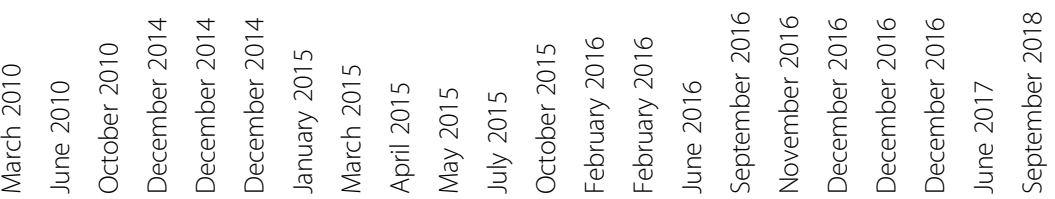




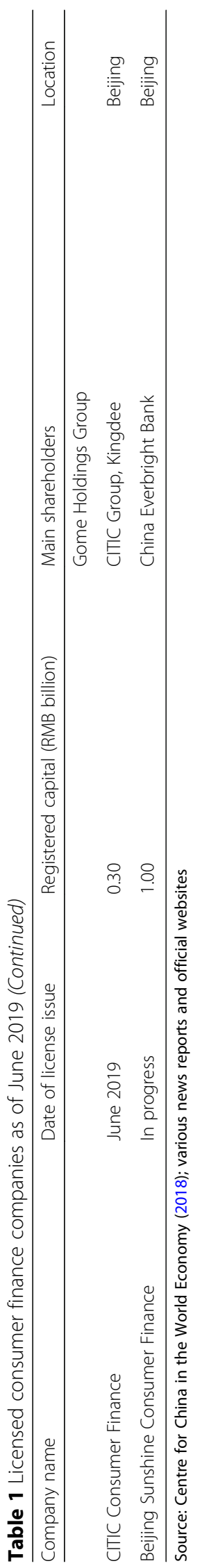


Table 2 Listed consumer finance companies: 2010-May 2019

\begin{tabular}{|c|c|c|c|c|c|}
\hline Company name & Security code & Exchange & $\begin{array}{l}\text { Listed date } \\
(\mathrm{m} / \mathrm{d} / \mathrm{y})\end{array}$ & $\begin{array}{l}\text { Market cap } \\
\text { (USD millions) }\end{array}$ & $\begin{array}{l}\text { Net proceeds } \\
\text { from IPO } \\
\text { (USD millions) }\end{array}$ \\
\hline $\begin{array}{l}\text { Dunxin Financial } \\
\text { Holdings Ltd. }\end{array}$ & DXF.A & $\begin{array}{l}\text { American Stock } \\
\text { Exchange }\end{array}$ & $11 / 23 / 2010$ & 577.1 & 85.8 \\
\hline China Lending Corp & CLDC.O & NASDAQ & $10 / 22 / 2014$ & 75.9 & NA \\
\hline China Rapid Finance Ltd. & XRF.N & $\begin{array}{l}\text { New York Stock } \\
\text { Exchange }\end{array}$ & $4 / 28 / 2017$ & 404.5 & 51.1 \\
\hline Qudian Inc. & QD.N & $\begin{array}{l}\text { New York Stock } \\
\text { Exchange }\end{array}$ & 10/18/2017 & 9630.9 & 841.3 \\
\hline Hexindai Inc. & HX.O & NASDAQ & $11 / 3 / 2017$ & 655.9 & 40.1 \\
\hline PPDAI Group Inc. & PPDF.N & $\begin{array}{l}\text { New York Stock } \\
\text { Exchange }\end{array}$ & $11 / 10 / 2017$ & 3932.0 & 199.4 \\
\hline Jianpu Technology Inc. & JT.N & $\begin{array}{l}\text { New York Stock } \\
\text { Exchange }\end{array}$ & $11 / 16 / 2017$ & 1392.0 & 162.5 \\
\hline Lexin Fintech Holdings Ltd. & LX.O & NASDAQ & $12 / 21 / 2017$ & 1753.3 & 94.4 \\
\hline Senmiao Technology Ltd. & AlHS.O & NASDAQ & $3 / 16 / 2018$ & 144.1 & 9.8 \\
\hline Golden Bull Ltd. & DNJR.O & NASDAQ & $3 / 20 / 2018$ & 67.2 & 4.5 \\
\hline CN Finance Holdings Ltd. & CNF.N & $\begin{array}{l}\text { New York Stock } \\
\text { Exchange }\end{array}$ & $11 / 7 / 2018$ & 517.0 & 41.6 \\
\hline Weidai Ltd. & WEI.N & $\begin{array}{l}\text { New York Stock } \\
\text { Exchange }\end{array}$ & $11 / 15 / 2018$ & 717.4 & 35.1 \\
\hline 360 Finance, Inc. & QFIN.O & NASDAQ & $12 / 14 / 2018$ & 2373.1 & 43.7 \\
\hline Jiayin Group Inc. & JFIN.O & NASDAQ & $5 / 10 / 2019$ & 864.0 & 29.8 \\
\hline
\end{tabular}

Source: Wind

Acknowledgements

The author would like to thank an anonymous referee and the editor for very valuable comments on an earlier version of this paper. All errors are the author's sole responsibility.

\section{Authors' contributions}

The author is the sole author of this paper, and makes full contribution to this paper. The author(s) read and approved the final manuscript.

\section{Funding}

This research did not receive any specific grant from funding agencies in the public, commercial, or not-for-profit sectors.

\section{Availability of data and materials}

The dataset used and/or analysed during the current study are available from the corresponding author on reasonable request.

\section{Competing interests}

The authors declare that they have no competing interests.

Received: 12 November 2019 Accepted: 6 March 2020

Published online: 01 April 2020

\section{References}

Allen, F. (2001). Do financial institutions matter? The Journal of Finance, 56(4), 1165-1175.

Badarinza, C., Campbell, J. Y., \& Ramadorai, T. (2016). International comparative household finance. Annual Review of Economics, 8, 111-144.

Barberis, N., \& Thaler, R. (2003). A survey of behavioral finance. Handbook of the Economics of Finance, 1(part B), $1053-1128$.

Campbell, J. Y. (2006). Household finance. The Journal of Finance, 61(4), 1553-1604.

Centre for China in the World Economy. (2018). Chinese consumer credit market research 2018. Beijing: Tsinghua University Retrieved from https://att.dahecube.com/4a5ab7de-1aa3-4754-a4d7-6e707d943d69 .

Chen, D., Li, X., \& Lai, F. (2017). Gender discrimination in online peer-to-peer credit lending: Evidence from a lending platform in China. Electronic Commerce Research, 17(4), 553-583.

Chen, X., Huang, B., \& Ye, D. (2018). The role of punctuation in P2P lending: Evidence from China. Economic Modelling, 68(1), 634-643. 
China Banking Regulatory Commission. (2009). Pilot management measures for consumer finance companies. Retrieved from http://www.gov.cn/gongbao/content/2010/content_1539397.htm

China Banking Regulatory Commission. (2012). Administrative measures for the capital of commercial banks (for trial implementation) (order no. 1). Retrieved from http://en.pkulaw.cn/display.aspx?cgid=176745\&lib=law

China Banking Regulatory Commission. (2013). Pilot management measures for consumer finance companies. Retrieved from http://www.nifd.cn/ResearchComment/Details/1229

China Banking Regulatory Commission. (2017a). Guiding opinions on improving the efficiency of the banking service to the real economy. Retrieved from http://www.cbrc.gov.cn/govView_86686E2A08A2419FA1499724D78EEA6D.html

China Banking Regulatory Commission. (2017b). Notice on standardizing and regulating "cash loan" businesses. Retrieved from http://www.jr.sz.gov.cn/sjrb/xxgk/zcfg/dfjrzc/xedkgs/201803/P020180301590002269310.pdf

China Banking Regulatory Commission. (2019). Guiding opinions on classifying online lending institutions and risk prevention Retrieved from https://finance.ifeng.com/c/7je4ILIAV3A

China Banking Regulatory Commission, Ministry of Education, and Ministry of Human Resources and Social Security of the PRC. (2017). Notice on Further Strengthening the Management of Campus Lending Regulations. Retrieved from http:/www. gov.cn/xinwen/2017-06/29/content_5206540.htm

China Family Finance Survey and Research Center. (2017). China's working-class credit development report. Southwestern University of Finance and Economics. Retrieved from https://chfs.swufe.edu.cn/Upload/\%E4\%B8\%AD\%E5\%9B\%BD\%E5\% B7\%A5\%E8\%96\%AA\%E9\%98\%B6\%E5\%B1\%82\%E4\%BF\%A1\%E8\%B4\%B7\%E5\%8F\%91\%E5\%B1\%95\%E6\%8A\%A5\%E5\%91\% 8A\%E8\%AF\%A6\%E7\%BB\%86\%E7\%89\%88.pdf

China International Capital Corporation. (2018). Thoughts on "household deleveraging." Retrieved from https://en.cicc.com/ cmscontent/18134.html

Daisuke, Y., Kim, J., \& Xuan, X. (2017). Overview of the development of consumer finance in China, Japan, and South Korea. In G. Wang, G. Zeng, \& X. Xiaoying (Eds.), Development of consumer finance in East Asia (pp. 19-41). New York: Palgrave Macmillan.

Devlin, J. F. (1995). Technology and innovation in retail banking distribution. International Journal of Bank Marketing, 13(4), $19-25$.

Dick, A. A., \& Lehnert, A. (2010). Personal bankruptcy and credit market competition. The Journal of Finance, 65(2), 655-686.

Ding, J., Huang, J., Li, Y., \& Meng, M. (2019). Is there an effective reputation mechanism in peer-to-peer lending? Evidence from China. Finance Research Letters, 30, 208-215.

Graham, J. R. (2003). Taxes and corporate finance: A review. The Review of Financial Studies, 16(4), 1075-1129.

Guiso, L., \& Sodini, P. (2013). Household finance: An emerging field. Handbook of the Economics of Finance, 2(part B), 1397-1532.

Guo, B., Wang, J., \& Wei, S. X. (2018). R\&D spending, strategic position and firm performance. Frontiers of Business Research in China, 12(1), 277-295.

Hao, Y., Liu, S., Jiesisibieke, Z. L., \& Xu, Y. J. (2019). What determines university students' online consumer credit? Evidence from China. SAGE Open, 9(1), 1-15.

Hynes, R., \& Posner, E. A. (2002). The law and economics of consumer finance. American Law and Economics Review, 4(1), 168-207.

Jiang, J., Liao, L., Wang, Z., \& Zhang, X. (2018). Government affiliation and peer-to-peer lending platforms in China. Available at SSRN: https://ssrn.com/abstract=3116516 or. https://doi.org/10.2139/ssrn.3116516.

Lardy, N. R. (2016). China: Toward a consumption-driven growth path. In Y. Zhou (Ed.), Seeking changes: The economic development in contemporary China (pp. 85-111). Singapore: World Scientific Publishing.

Li, J., Hsu, S., Chen, Z., \& Chen, Y. (2016). Risks of P2P lending platforms in China: Modeling failure using a cox hazard model. The Chinese Economy, 49(3), 161-172.

Liu, K. (2017). China's interest rate pass-through to commercial banks before and after interest rate liberalization. Economic Affairs, 37(2), 279-287.

Liu, K. (2018a). Chinese manufacturing in the shadow of the China-US trade war. Economic Affairs, 38(3), 307-324.

Liu, K. (2018b). Chinese consumption myth (unpublished working paper). Australia: The China Studies Centre, University of Sydney.

Liu, K. (2018c). Why does the negotiable certificate of deposit matter for Chinese banking? Economic Affairs, 38(1), 96-105.

Liu, K. (2018d). Chinese banking sector's intrafinancial system debt issue. Journal of Asia-Pacific Business, 19(3), 166-181.

Liu, K. (2019). China's visible hand: An analysis of the Chinese government's intervention in its economy during 2015-2017. Journal of Business and Economic Studies, 23(1), 36-54.

Liu, K. (2020). China's macroprudential policies: Framework, implementations and implications. Journal of Financial Compliance, 3(3), 273-285.

Mandell, L., \& Klein, L. S. (2009). The impact of financial literacy education on subsequent financial behavior. Journal of Financial Counseling and Planning, 20(1), 15-24.

Nanda, K., \& Kaur, M. (2016). Financial inclusion and human development: A cross-country evidence. Management and Labour Studies, 41(2), 127-153.

National Internet Finance Association of China. (2017). Group standards of Internet finance: information disclosure, Internet consumer finance. Retrieved from http://www.nifa.org.cn/nifa/2955675/2955761/2968250/index.html

Oxhorn, E. (2012). Consumer finance and financial repression in China. East Asia Law Review, 7(2), 374-427.

The People's Bank of China. (2005). Administrative Measures for the Issuance of Financial Bonds in the National Inter-bank Bond Market. Retrieved from http://www.nafmii.org.cn/flfg/rhgz/201202/t20120226_1558.html

The People's Bank of China. (2008). Guiding opinions on the pilot operation of small-sum loan companies (No. 23). Retrieved from http://www.cbrc.gov.cn/chinese/home/docDOC_ReadView/2008050844C6FDE83536CF44FFF6E85E5BC32C00.html

The People's Bank of China. (2016). Financial consumer rights protection implementation measures. Beijing: Retrieved from http://www.gov.cn/gongbao/content/2017/content_5213211.htm .

The People's Bank of China \& China Banking Regulatory Commission. (2016). Guidance on Increasing Financial Support for New Consumption Areas. Retrieved from http://www.cbrc.gov.cn/chinese/home/docDOC_ReadView/FB21DA0230164DC6 80DE56502CB573DD.html

The People's Bank of China, China Bank and Insurance Regulatory Commission, China Securities Regulatory Commission, \& State Administration of Foreign Exchange. (2018). Guiding Opinions on Regulating Asset Management Business of Financial Institutions. Retrieved from http://www.pbc.gov.cn/goutongjiaoliu/113456/113469/3529600/index.html 
The People's Bank of China,the Ministry of Industry and Information Technology of People's Republic of China (PRC), the Ministry of Public Security of the PRC,the Ministry of Finance of the PRC, State Administration for Industry and Commerce of the PRC, China Bank and Insurance Regulatory Commission, China Securities Regulatory Commission, \& Cyberspace Administration of China. (2015). Guideline on promoting the healthy development of internet finance. Beijing: Retrieved from http://www.pbc.gov.cn/goutongjiaoliu/113456/113469/2813898/index.html.

Senbet, L. W., \& Wang, T. Y. (2012). Corporate financial distress and bankruptcy: A survey. Foundations and Trends ${ }^{\circledast}$ in Finance, $5(4), 243-335$

Shi, M., \& Yan, X. (2017). Heterogeneous consumers, search and retail formats. Frontiers of Business Research in China, 11(4) $525-544$

Shi, M., Zhou, J., \& Jiang, Z. (2019). Consumer heterogeneity and online vs. offline retail spatial competition. Frontiers of Business Research in China, 13(2), 231-249.

State Council. (2015). Non-deposit lending institution regulations (draft for comments). Retrieved from http://www.gov.cn/ xinwen/2015-08/12/content_2911852.htm

State Council. (2016a). Advancing Inclusive Financial Development, 2016-2020. Retrieved from http://www.gov.cn/zhengce/ content/2016-01/15/content_10602.htm

State Council. (2016b). Implementation plan for the special rectification of Internet financial risks. Retrieved from http://www. gov.cn/_hengce/content/2016-10/13/content_5118471.htm

State Council. (2018). Implementation plan for improving and promoting consumption (2018-2020). Retrieved from http:// www.gov.cn/zhengce/content/2018-10/11/content_5329516.htm

State Council. (2019). Accelerating the improvement of the market entity exit system reform plan. Retrieved from http://www. gov.cn/guowuyuan/2019-07/16/5410058/files/bbaef6612fed4832b70a122b39f1d5bd.pdf

Trumbull, G., \& Tufano, P. (2011). A brief post-war history of US consumer finance (working paper no. 11-058). Business History Review, 85(3), 461-498.

Tsinghua University. (2019). Consumer finance industry insight report. Retrieved from http://www.baironginc.com/index.php/ index/shownew/n_id/179.html

Tufano, P. (2009). Consumer finance. Annual Review of Financial Economics, 1(1), 227-247.

Zhou, W., Arner, D. W., \& Buckley, R. P. (2015). Regulation of digital financial services in China: Last mover advantage. Tsinghua China Law Review, 8(1), 25-62.

\section{Publisher's Note}

Springer Nature remains neutral with regard to jurisdictional claims in published maps and institutional affiliations.

\section{Submit your manuscript to a SpringerOpen ${ }^{\circ}$ journal and benefit from}

- Convenient online submission

- Rigorous peer review

- Open access: articles freely available online

High visibility within the field

- Retaining the copyright to your article

Submit your next manuscript at $\boldsymbol{s p r i n g e r o p e n . c o m ~}$ 